УДК 351.82:334.7

DOI https://doi.org/10.32836/2310-9653-2019-2-136-142

\author{
O. V. Akilina, Ph.D. in Economics, \\ Associate Professor, \\ Head of Management Departmen \\ of the Borys Grinchenko Kyiv University
}

V. V. Pavliuk, Ph.D. in Public Administration, Associate Professor, Deputy of the Director of the Education and Research Institute of Finance and Banking, Head of Scientific Work and International Relations of the National University of the State Fiscal Service of Ukraine

\title{
ACTUAL IMPORTANCE OF PUBLIC-PRIVATE PARTNERSHIP FOR PROVIDING ECONOMIC MODERNIZATION OF CITY KYIV UNDER EUROINTEGRATION
}

Considering the potential of Public-Private Partnership (PPP), it can be stated that further development of mutually beneficial cooperation can shape a basis for making more efficient use of resources and providing modern city socio-economic development under eurointegration. Kyiv should trigger economic transformation in Ukraine, in particular, by introducing PPP projects which must ensure: overcoming economic growth infrastructural constraints; enhancing the quality of life; environmental improvement; unleashing small and medium-sized businesses industrial potential; innovation; businesses and public involvement into achieving these goals.

Key words: Public-Private Partnership, development of local community, city.

О. В. Акіліна, В. В. Павлюк. Актуалітети державно-приватного партнерства у вирішенні завдань економічної модернізації міста Київа в умовах євроінтеграції

Ураховуючи потенціал державно-приватного партнерства, можна констатувати, що подальший розвиток взаємовигідної співпраці може стати базою для підвищення ефективності використання ресурсів і вирішення завдань соціально-економічного розвитку сучасного міста в умовах євроінтеграції. Київ має дати початок економічним перетворенням в Україні, зокрема, шляхом упровадження проектів державно-приватного партнерства, які мають забезпечити: подолання інфраструктурних обмежень економічного зростання; підвищення якості життя людей; поліпшення стану навколишнього середовища; розкриття виробничого потениіалу малого та середнього підприємництвва; впровадження інноваиій; залучення для досягнення зазначених иџілей бізнесу та громадськості.

Такий формат співпраці забезпечує підвищення якості $і$ зростання доступності соиіально-економічної інфраструктури та факторів виробництва, капіталу, робочої сили, технологій, щзо суттєво впливає на ефективність механізмів державного управління розвитком міста. Сталий розвиток міст та інших адміністративно-територіальних утворень за рахунок використання державно-приватного партнерства призводить до зменшення витрат усіх рівнів під час реалізаиії інфраструктурних проектів та дозволяє підвищити в такий спосіб ефективність бюджетного сектора з погляду відповідності потребам розвитку економіки.

Одним із напрямків розвитку держсавно-приватного партнерства в забезпеченні регіональної розбудови є залучення у проекти закладів вищої освіти, щсо розташовані на території відповідних регіонів, міст, районів. Здійснення на базі ЗВО високотехнологічних розроблень, можливість трансферу

(C) O. V. Akilina, V. V. Pavliuk, 2019 
технологій дозволяють розвивати діючі або новостворені підприємства. Створення стартапів, які поєднують бізнесові компетентності та теоретичні знання, оновлює діючу інфраструктуру міста. При цьвому кадровий потенціал $3 В О$ має бути залучений до розроблення програм розвитку міст.

Для розвитку державно-приватного партнерства в м. Києві, на нашу думку, потрібні: політична воля і сильне лідерство на місцевому рівні; державна підтримка на центральному рівні; стабільна економічна ситуація; використання кращих зразків міжнародного досвіду; чесна конкурениія.

Ключові слова: державно-приватне партнерство, розвиток територіальної громади, місто.

Introduction and problem statement. Development of efficient institutions for interaction between state and businesses is one of the important conditions of successful realization socio-economic modernization both at national and regional levels. Such interaction promotes increasing in GDP growth, enhancing the effectiveness of public sector concerning compliance with the economic development requirements, cost reduction at all levels while implementing infrastructural projects. Furthermore, it provides improving the quality and increasing availability of socio-economic infrastructure and production factors, capital, labor force, technologies, as well as business-to-business cooperation linkages, and encourages export and attraction of foreign investments.

City sustainable development security is a basic principle of current regional development. However, Ukraine lags significantly behind developed countries by the indicators of city sustainable development. There are a lot of difficulties resulting from agglomerating a range of complicated social, economic and environmental problems in this sector. Their solution is impossible without private sector engagement, Public-Private Partnership, in particular.

Literature review. The issues of local communities development is highlighted in works of many scholars, such as V. Babayev, O. Korotych, N. Mel'tyuhova, Yu. Kuts, V. Mamonova etc. Scientists also pay a great deal of attention to the research into PPP. For instance, the studies by O. Alimov, B. Danilishin, O. Dlugopolskiy, I. Neykova, S. Onishko, S. Pakulin, S. Pidgayets and others are devoted to this issue. Socio-political, economic and social transformations in Ukrainian society, considering by the researchers, encourage the need for changes, though the lack of awareness of changes framework, methods, tools and instruments is observed, including the Public-Private Partnership.

The general scientific methods of research are applied in the article. But the methodological ground for the study of Public-Private Partnership challenges should be presented with the help of integral approach which is based on a variety of conceptions, in particular, change management model which allows to consider the algorithm of PPP revitalization from different points of view.

The objective of the study. To justify the need for Public-Private Partnership revitalization in Kyiv aimed at attracting private investments to provide economic modernization of the city under eurointegration.

Presentation of the material. The process of establishment and use of Public-Private Partnership (PPP) services in Ukraine, as well as dialogue between state and businesses concerning this issue has just been launched. Businesses accumulate a great amount of resources to ensure city development. It is not only investments which are considered but also the quality of staff that possess best managerial, organizational and financial skills and technologies. The search and selection of the ways to make the most of them specify significantly an opportunity for city economy development and solution its social problems.

A range of countries have to face with a lack of infrastructure like congested roads and recreational facilities with bad service, deterioration in water supply system, schools and hospital infrastructure. Such shortage results in decline in birth rate and life expectancy, whereas increase in accidents and health problems. It was PPP engagement that helped find the way out of such situation for the authorities of many countries making available private financial resources. In developed 
European capitals nearly $10-30 \%$ of all investments in their development are given by the government, while the other funds are provided by private sector [1].

The highest performance is shown by PPP projects in the following spheres: schools, hospitals, prisons, defences (the UK); energy, transport, environmental protection, water resources, sewerage, recreational objects, informational technologies (Canada); transport projects (Greece, Ireland, Australia, Spain); projects combining environmental protection, commercial interests and life support of rural places (the USA) $[1 ; 2$, p. 293].

Nonetheless, nearly $80 \%$ of Kyiv investments are currently financed with the state resources that essentially differs from the practice mentioned above. According to world statistics, the outer investments in municipal sphere reduce the cost of services by $25 \%$, whereas shortening the period of the work performed by $30 \%$ without significant tariffs raising. Yet, so far there have been few examples of successful PPP projects in Kyiv, which confirms the low level of Ukrainian capital investment appeal. Meanwhile, Kyiv needs revitalization of such projects, particularly, concerning current infrastructure modernization which is fairly drastical to achieve sustainable development Goals.

It is of actual importance to study and introduce world experience concerning PPP aimed at meeting the requirements of humans and communities with further implementation of this model in Ukraine. Occasionally realization of projects on transport systems renewal and maintenance launch PPP development; this trend is also observed in Kyiv. Nowadays several PPP projects on road traffic safety and "Tram-Train" system development are in the process of preparation. Reducing a number of road traffic accidents, creating jobs and increasing the level of driving behavior in the city, "Introduction of violation system in the sphere of ensuring automatic road traffic safety in Kyiv" should attract excess financial resources to city budget, as well as reliable manager to handle with this system in the future.

Within "Tram-Train" project the creation of dual-mode framework which allows to join leaf and right banks with extra speedy system of public transport avoiding any interference with existing framework of city infrastructure. Though it should be mentioned that up to July, 1, 2018, according to the data of Ministry of economic development and trade of Ukraine, there were only 192 PPP contracts in Ukraine, including 126 contracts that are not implemented (the tern of 4 contracts is invalid, 9 contracts are broken, 113 contracts are failed). As for the Kyiv State Administration, according to this Ministry data, there was no PPP contract signed.

To estimate the situation concerning revitalization of such tool as Public-Private (Municipal-Private) Partnership the analysis of Kurt Lewin's force field model should be applied (fig. 1).

To extend force field change there are the following opportunities:

- attracting long-term investments into subsistence sectors of city economy;

- engaging efficient management;

- improving the quality and range of services;

- creating competitive environment;

- diminishing infrastructural restraints of growth.

Though, to the author's mind, there are essential risks of individual, group and systematic opposition to changes, in particular, the following ones:

- a chance to lose or weaken the control by state authorities at the cost of tariffs raising and services quality improving;

- negative social consequences of business-partner's bankruptcy causing the lack of trust to the state (municipal) authorities from localities;

- shaping excess conditions for corruption by the partnership due to the terms of authorization procedures opaque and flaws in local legal system;

- high risks of capital expenditures and non-compliance of budgetary commitments. 


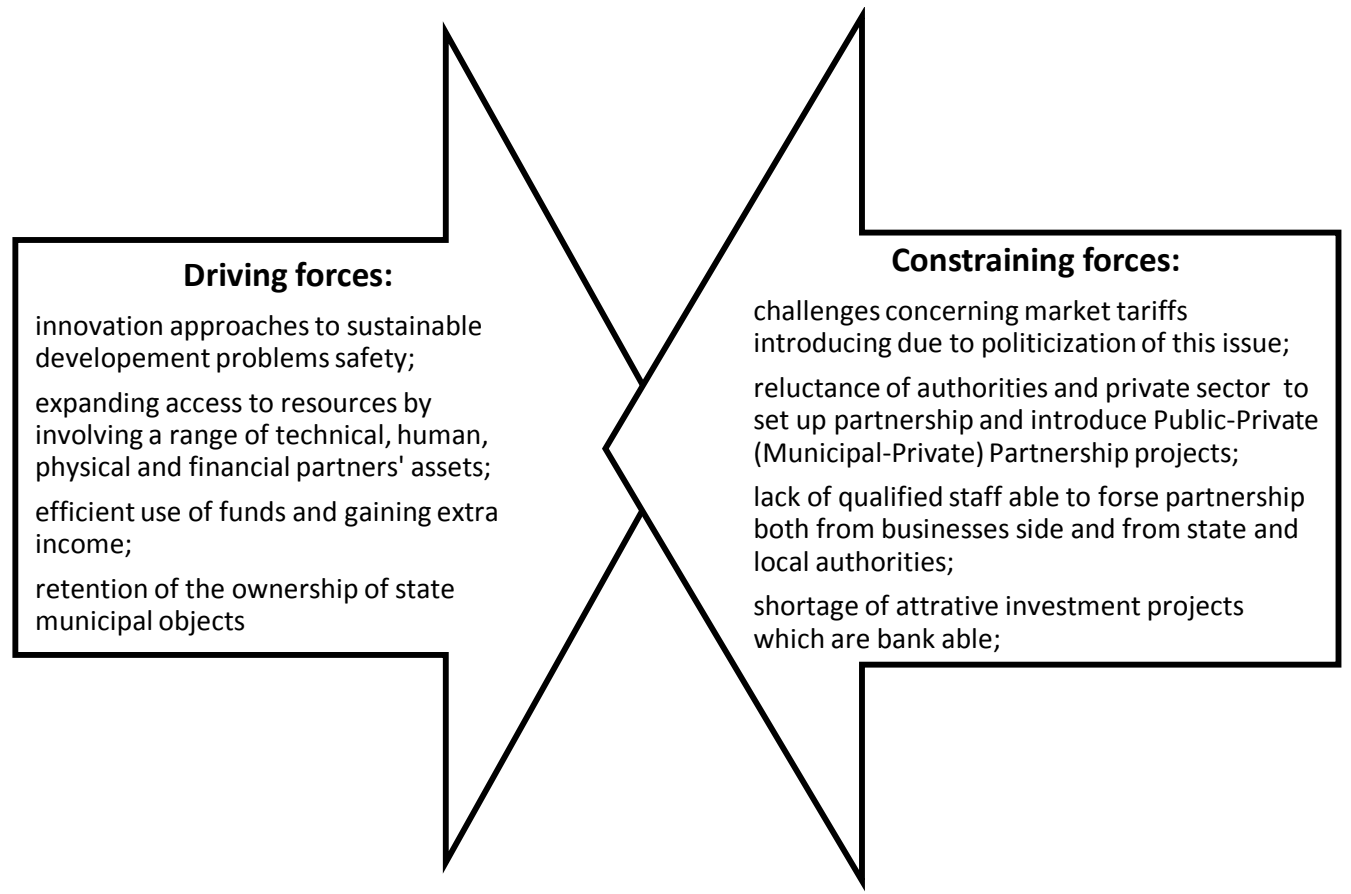

Fig.1. Force field change model

To reduce resistance the base of partnership is grounded on the principles ensuring to support interaction like principles of equity, transparency and mutual benefit, apart from the aim to be complied.

There may be failures at any stage of partnership process which is natural but able to demoralize partners and be of insurmountable barrier. So, to reduce change resistance, the manifestation of 'small victories' is a must. Within the process studied it should be the following:

- the performance that cross-sectoral collaboration encourages to improve professional indicators of efficiency;

- reassuring all participants of partnership that each of parties take some advantage of cross-sectoral collaboration;

- demonstration the importance of new linkages, their variety, range and impact to the partners;

- promotion of previous experience concerning the cooperation between businesses and local authorities as for the issues of beautification of the local areas grounded on the sustainable development principles through mass media and the Internet resources.

As mentioned above, among the forces which constrain changes there is a lack of qualified staff which clearly realize what PPP is according to international standards, are concerned that it is the helping hand of local infrastructure modernization without significant state budget expenses, as well as encourage consistently to introduce successful PPP program in Kyiv taking no notice of any political priorities. To the authors' mind, the events to attract municipal higher educational establishments may be one of the ways to solve this problem. As priorities to intensify higher educational establishments innovation potential the following ones should be noted:

- Encouraging implementation of high-tech developments and technology transfer into existing or newly-formed enterprises;

- Creating the start-ups which combine business skills and theoretical knowledges; 
- Adjustment of syllabus with public administration through introduction of specialized courses(modules) concerning PPP;

- Engagement of higher educational establishments staff to work out the programs of city development.

World practice reveals a number of models, forms, types and specific variants which promotes realizing partnership relations between tha state and businesses. Being aware of the fact of the use such forms as contracts, rental agreements, including leasing, concession, joint venturing and distribution agreements, Ukraine chose concession as the most often form of PPP services (see table 1) [3].

Ukrainian legislation define concession as a whole, providing a wide circle of duties and privacy's responsibilities, including functions of handling as well as ownership to create and design construction which is a concession object. [4]

Table 1

Results of Public-Private Partnership projects realization in the first half of 2018

\begin{tabular}{|l|c|c|c|c|}
\hline \multirow{2}{*}{ Region } & \multicolumn{4}{c|}{ Up to 1,July,2018 (valid) } \\
\cline { 2 - 5 } & concession & Joint venture & PPP contract & Total \\
\hline Donetsk & 2 & 2 & 0 & 4 \\
\hline Zhitomir & 0 & 1 & 0 & 1 \\
\hline Zakarpatya & 4 & 5 & 0 & 9 \\
\hline Zaporizhya & 4 & 0 & 0 & 1 \\
\hline Ivano-Frankivs'k & 1 & 0 & 0 & 10 \\
\hline Kyiv & 10 & 0 & 0 & 1 \\
\hline Kirovograd & 0 & 1 & 0 & 1 \\
\hline Luhansk & 1 & 0 & 0 & 4 \\
\hline Lviv & 3 & 1 & 0 & 15 \\
\hline Mykolaiv & 14 & 1 & 0 & 6 \\
\hline Odessa & 0 & 6 & 0 & 1 \\
\hline Poltava & 0 & 5 & 0 & 2 \\
\hline Kharkiv & 1 & 0 & 0 & 1 \\
\hline Kherson & 1 & 1 & 0 & 1 \\
\hline Khmelnitskiy & 0 & 0 & 1 & 66 \\
\hline Chernigiv & 0 & 1 & 0 & \\
\hline Total & 41 & 24 & 1 & \\
\hline
\end{tabular}

Nevertheless the percentage of failures in PPP in Ukraine mainly results from general regulatory and legal environment in which state partner prevails the private ones. Concession is not indulgency, as there are situations which requires more than investments lack. For instance, management contracts are more widespread in water supply and sewerage (nearly $70 \%$ of projects). As in Ukraine concession contracts comprise significant part of all projects, investment burden is imposed from local budget only on users. That is why we emphasize that variety of PPP instruments, forms and methods promotes wider use of private capital for solving a number of problems concerning public interest, in particular, those regarding economy modernization.

At the stage of changes institutionalization the specific obstacles appear. The analysis of strategic state documents on adaptation sustainable development Goals in Ukraine [5] points that the lowest level of sustainable development Goals integration (13\%) relates to city development. So the specific work is necessary to eliminate these obstacles. 
While estimating changes, they can be efficient as for Public-Private Partnership (Municipal-Private Partnership) revitalization provided that:

- such partnership is aimed at achieving the goals set - project or program are successfully implemented;

- results achieved are recognized by project beneficiaries, stakeholders and Kyiv local community;

- partnership becomes stable and independent;

- partnership creates "added value" which provides essential positive results for each partner.

Conclusions. Thus, Public-Private Partnership is efficient mechanism of attracting private investments to solve the issues providing city economy modernization. Kyiv should trigger economic transformation in Ukraine, in particular, by introducing PPP projects which must ensure: overcoming economic growth infrastructural constraints; enhancing the quality of life; environmental improvement; unleashing small and medium-sized businesses industrial potential; innovation; businesses and public involvement into achieving these goals. But it is complicated and responsible case which requires highly qualified staff, developed institutional environment, improvements in the investment climate and tariffication depoliticization.

In our opinion, to develop Public-Private Partnership in Kyiv it is of vital importance the following:

- political will and strong leadership at the local level;

- stable economic situation, as partnership projects are long-term, as a rule;

- state support at central level, establishment the single coordinative body;

- study and use the best world experience;

- fair competition and qualitative contests with employment of experienced operators (wellknown corporative brands).

\section{Bibliography:}

1. Yescombe E. R. Public-Private Partnerships: Principles of Policy and Finance. London : Yescombe Consulting Ltd, 2007. 368 p.

2. Підгаєць С. Свропейський досвід застосування моделей державно-приватного партнерства. Журнал європейської економіки. 2017. Т. 10. №. 3. С. 291-305.

3. Офіційний сайт Міністерства економічного розвитку i торгівлі. URL : http://www.me.gov.ua/Documents/Detail?lang=uk-UA\&id=62a9b6fb-27ff-462a-b351-eeeadfb26b6 f\&title=StanZdiisnenniaDppVUkraini (дата звернення : 22.12.2018).

4. Про концесії : Закон України від 16.07.1999 р. № 997-XIV. Дата оновлення: 25.03.2018. URL : https://zakon.rada.gov.ua/laws/show/997-14 (дата звернення : 24.04.2019).

5. Аналіз державних стратегічних документів України щодо врахування адаптованих для України Цілей Сталого Розвитку до 2030 року: резюме аналітичної доповіді / за заг. ред. А.А. Максюти. Київ : Інститут суспільно-економічних досліджень, 2017. 20 с. URL : http://iser.org.ua/uploads/files/ISED_Resume-UKR_v06\%20FINAL.pdf.

\section{References:}

1. Yescombe E. R. (2007), Public-Private Partnerships: Principles of Policy and Finance, Press Yescombe Consulting Ltd, London, $368 \mathrm{p}$.

2. Pidhaiets S. (2017), "Yevropeiskyi dosvid zastosuvannia modelei derzhavno-pryvatnoho partnerstva" ["European experience of Public-Private Partnership models introduction"], journal Zhurnal yevropeiskoi ekonomiky [Journal of European economy], vol. 3 (10), pp. 291-305 [Ukraine].

3. Ministry of economic development and trade (2018), official site. URL: http://www.me.gov.ua/Documents/Detail?lang=uk-UA\&id=62a9b6fb-27ff-462a-b351-eeeadfb26b6 f\&title=StanZdiisnenniaDppVUkraini (related to 22.12.2018) [Ukraine]. 
4. VRU, Law of Ukraine (1999), Pro kontsesii [Law of Ukraine "On concession"], dated July 16, 1999 No. 997-XIV. URL: https://zakon.rada.gov.ua/laws/show/997-14 (related to 24.04.2019) [Ukraine].

5. Edited by Maksiuty A. A. (2017). Analiz derzhavnykh stratehichnykh dokumentiv Ukrainy shchodo vrakhuvannia adaptovanykh dlia Ukrainy Tsilei Staloho Rozvytku do 2030 roku [Analysis of state strategic documents of Ukraine on adaptation sustainable development Goals in Ukraine till 2030], Resume of analytical report, Press Institute of socio-economic studies, Kyiv. URL: http://iser.org.ua/uploads/files/ISED_Resume-UKR_v06\%20FINAL.pdf [Ukraine].

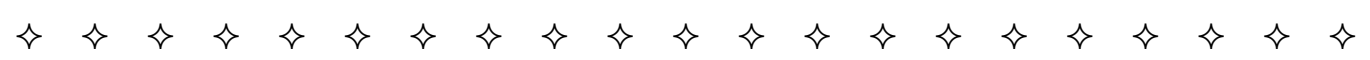

УДК 353.2

DOI https://doi.org/10.32836/2310-9653-2019-2-142-148

О. М. Бородіна, кандидат економічних наук, доцент, ВНЗ «Київський університет ринкових відносин»

л. І. Плотнікова, кандидат економічних наук, доцент, ВНЗ «Київський університет ринкових відносин»

\section{СТРАТЕГІЧНІ ДОМІНАНТИ РЕГІОНАЛЬНОГО АДМІНІСТРУВАННЯ В СУЧАСНИХ УМОВАХ}

Статтю присвячено аналізу складових системи публічного управління та адміністрування регіональним розвитком в умовах реформи місцевого самоврядування та децентралізації влади. Зазначено, що однією з умов реформи є побудова механізму сталого розвитку регіонів, який забезпечується базовими інститутами, відповідальними за реалізачію стратегічних домінант розвитку регіонів. Визначено, що формування механізму сталого розвитку регіону необхідне для виконання чотирьох стратегічних завдань: підвищення конкурентоспроможності регіонів $і$ зміцнення їх ресурсного потенціалу; розвитку людських ресурсів; розвитку міжрегіональної співпращі; створення інституційних умов для розвитку регіонів.

Ключові слова: децентралізація, місиеве самоврядування, реформа, сталий розвиток, регіональна політика.

O. M. Borodina, L. I. Plotnikova. Strategic dominants of the regional administration in the modern context

The article focuses on the analysis of the components of the system of public management and administration of the regional development in a reformed local self-government and decentralization of power. It has been determined that the reform of local self-government and decentralization of power involves overcoming the challenges the country faced, in particular: dependence of the regions on the center; infrastructure and financial weakness of the communities; degradation of rural areas; high level of subsidy provision for the communities; low investment attractiveness of the territories, etc. The reform is based on three principles: delegation of authorities from the center to the lowest possible level; in accordance with the delegated authorities, the financial resources should be transferred and the state control should be maintained over the activities of local self-government bodies. It is substantiated that the mechanisms of the regional management and administration at the present stage of market

() О. М. Бородіна, Л. І. Плотнікова, 2019 